\title{
Pengaruh Usia dan Jenis Kelamin Terhadap Pengetahuan serta Perilaku Penggunaan Suplemen si Masa Pandemi pada Mahasiswa lik Bhakti Wiyata
}

\author{
Esti Ambar Widyaningrum¹, Wika Admaja' ${ }^{1}$, Lelly Winduhani Astuti ${ }^{1}$, Badiaturisa Masyriqoh²
}

\author{
1Dosen Fakultas Farmasi/IIK Bhakti Wiyata Kediri \\ 2Mahasiswa Prodi S1 Farmasi/IIK Bhakti Wiyata Kediri \\ ^Email : esti.ambar@iik.ac.id
}

(Submit 19/12/2021, Revisi 20/12/2021, Diterima 30/12/2021, Terbit 31/12/2021)

\begin{abstract}
Abstrak
Latar belakang: Pada akhir tahun 2019 ditemukan adanya temuan virus baru SARSCoV-2 dan penyakitnya disebut Corona Virus 2019 (COVID-19). Virus ini dapat menyebabkan berbagai gangguan terutama gangguan pada saluran pernapasan mulai dari flu biasa sampai sindrom pernapasan akut. Upaya pemerintah dan masyarakat guna mencegah penyebaran virus tersebut yaitu dengan protokol $5 \mathrm{M}$ serta dengan menguatkan imun yang salah satunya melalui konsumsi suplemen kesehatan, baik diperoleh melalui resep dokter maupun secara bebas di apotek. Diperlukan pengetahuan yang memadai agar pemilihan dan penggunaan suplemen aman dan rasional. Tujuan: Untuk mengetahui tingkat pengetahuan dan perilaku serta pengaruh usia dan jenis kelamin terhadap pengetahuan serta perilaku penggunaan suplemen yang rasional pada mahasiswa S1 Farmasi IIK Bhakti Wiyata Kediri selama pandemi COVID-19. Metode: Penelitian observational analitik secara cross sectional dengan responden mahasiswa S1 Farmasi IIK Bhakti Wiyata Kediri. Teknik pengambilan sampel menggunakan purposive sampling. Instrumen dalam penelitian ini yaitu kuesioner online yang disebarkan melalui grup whatsapp pada tiap angkatan. Hasil: Data diperoleh dari 372 responden dan dianalisis dengan uji Chi-Square. Hasil penelitian menunjukkan tingkat pengetahuan mayoritas cukup baik 58,9\% dengan perilaku positif $56,2 \%$. Dari analisis dengan Chi-Square diketahui ada pengaruh usia terhadap pengetahuan dengan $p$ value $0.000 \leq 0.05$ tetapi tidak ada pengaruh usia terhadap perilaku $(0.0617>0.05)$. Berdasarkan jenis kelamin diketahui ada pengaruh jenis kelamin terhadap pengetahuan serta perilaku ( $p$ value $\leq 0.05)$ Kesimpulan: Ada pengaruh usia, jenis kelamin terhadap pengetahuan dan perilaku, sedangkan usia tidak berpengaruh terhadap perilaku penggunaan supplemen kesehatan peningkat imunitas tubuh selama pandemic COVID-19.
\end{abstract}

Kata Kunci : Suplemen, Pengetahuan, Perilaku, Usia, Jenis Kelamin 


\section{Pendahuluan}

Kesehatan merupakan keadaan sehat baik secara fisik, mental, spiritual, ataupun sosial pada setiap orang ${ }^{(1)}$. Masalah dalam bidang kesehatan saat ini menjadi salah satu faktor yang harus diperhatikan terutama ketika pada akhir tahun 2019 dunia mulai dikejutkan dengan adanya virus baru yang berasal dari Wuhan, Provinsi Hubei di China. Awalnya virus ini dinamakan dengan novel Coronavirus (2019-nCoV) yang kemudian pada tanggal 12 Februari 2020 WHO secara resmi menetapkan nama baru dengan sebutan Coronavirus Disease (COVID-19). Virus ini dapat menyebabkan penyakit pada saluran pernapasan mulai dari flu biasa bahkan sindrom pernapasan akut berat( ${ }^{(2)}$.

Virus tersebut dapat menyebar cepat ke seluruh negara didunia termasuk Indonesia. Tingkat mortalitas COVID-19 di Indonesia sebesar 8,9\%, angka ini merupakan angka mortalitas tertinggi di Asia Tenggara( ${ }^{(3)}$. Usaha pemerintah guna menangani masalah ini yaitu melakukan upaya kesehatan berupa promotif dan preventif dengan menerapkan protokol kesehatan 5M serta dengan meningkatkan imunitas tubuh. Ada berbagai macam cara untuk meningkatkan imunitas tubuh, diantaranyanya dengan mengonsumsi suplemen Kesehatan(2).

Pengertian suplemen kesehatan berdasarkan BPOM (2019) merupakan produk yang dimaksudkan sebagai pelengkap kebutuhan zat gizi makanan yang dapat mengandung satu atau lebih bahan berupa vitamin, mineral asam amino atau bahan lain yang berasal dari tumbuhan maupun bukan tumbuhan dan memiliki nilai gizi serta efek fisiologis dalam jumlah terkonsentrasi. Peran suplementasi seperti vitamin C, vitamin $D$, Zinc berpotensi dapat mempengaruhi respon imun dan telah dihipotesiskan dapat sebagai pencegahan dari virus COVID-19(4). Vitamin C bertindak sebagai antioksidan yang penting untuk produksi kolagen dan karnitin yang berkontribusi terhadap peningkatan dan pertahanan sistem kekebalan tubuh(2). Selain itu beberapa mekanisme vitamin $D$ seperti menginduksi cathelicidin dan defensin dapat mengurangi risiko infeksi. Pada vitamin E dan Zinc juga dapat berperan penting dalam fungsi kekebalan tubuh(5).

Penggunaan suplemen tersebut dapat dilakukan dengan konsultasi dokter ataupun diperoleh secara bebas (swamedikasi) dari apotek. Diperlukan pengetahuan yang memadai supaya dalam melakukan swamedikasi dengan suplemen dapat aman serta rasional. Dampak negatif dalam melakukan swamedikasi yang tidak rasional dapat menimbulkan masalah kesehatan akibat salah dalam menggunakan obat, efek pengobatan yang tidak tercapai, efek samping yang tidak diinginkan, serta overuse dalam penggunaan obat ${ }^{(6)}$.

Berdasarkan hal tersebut peneliti ingin mengetahui pengaruh karakteristik responden (usia dan jenis kelamin) terhadap pengetahuan serta perilaku swamedikasi dengan suplemen pada mahasiwa S1 Farmasi IIK Bhakti Wiyata Kediri selama pandemi COVID-19. 


\section{Metode}

Penelitian ini menggunakan metode observasional analitik dengan pendekatan cross sectional. Penelitian dilakukan di Fakultas Farmasi Institut IImu Kesehatan Bhakti Wiyata Kediri. waktu penelitian ini di mulai pada bulan Februari 2021 sampai dengan April 2021. Pada penelitian ini populasi yang digunakan yaitu mahasiswa S1 Farmasi Institut IImu Kesehatan Bhakti Wiyata Kediri. Teknik sampling yang digunakan pada penelitian ini yaitu purposive sampling dimana penulis menentukan kriteria inklusi dan eksklusi dari responden dan didapatkan 372 responden.

Variabel penelitian ada 2, yaitu variabel independen dan variabel dependen. Pada penelitian ini variabel independen (variabel bebas) yaitu usia, jenis kelamin dan pendidikan sedangkan variabel dependen (variabel terikat) yaitu pengetahuan dan perilaku penggunaan suplemen kesehatan dengan suplemen. Data yang digunakan dalam penelitian ini yaitu data primer dengan menggunakan instrumen penelitian kuesioner online yang disebarkan melalui whatsapp grup tiap angkatan. Metode pengumpulan data yang digunakan yaitu menggunakan metode kuantitatif yang dikumpulkan melalui pengisian kuesioner secara online

Pengolahan data dalam penelitian ini dilakukan dengan cara editing, coding, processing dan cleaning. Digunakan skala guttman untuk mengetahui tingkat pengetahuan responden dan skala likert untuk mngetahui tingkat perilaku responden. Dari data yang diperoleh tersebut, dilakukan analisis data dengan uji Chi-Square untuk mengetahui pengaruh usia, jenis kelamin dan pendidikan terhadap pengetahuan serta perilaku swamedikasi dengan suplemen pada mahasiswa S1 Farmasi IIK Bhakti Wiyata Kediri. Penelitian ini telah mendapatkan Surat Keterangan Kelayakan Etika Penelitian dari Komite Etika Penelitian IIK Bhakti Wiyata Kediri No : 80/PP2M-KE/II/2021.

\section{Hasil}

\section{Karakteristik Sampel Penelitian}

Tabel 1. Karakteristik Sosiodemografi Responden

\begin{tabular}{ccccc}
\hline Variabel & Karakteristik & Total (N) & Swamedikasi & $\begin{array}{c}\text { Tidak } \\
\text { Swamedikasi }\end{array}$ \\
& & & $\mathbf{N}(\%)$ & $\mathbf{N}(\%)$ \\
\hline Usia & $16-20$ tahun & 310 & $185(49.7)$ & $125(54.1)$ \\
& $21-25$ tahun & 288 & $182(48.9)$ & $106(45.9)$ \\
& 26-30 tahun & 3 & $3(0.8)$ & 0 \\
Jenis Kelamin & Laki-laki & 120 & $73(19.6)$ & $47(20.3)$ \\
& Perempuan & 483 & $299(80.4)$ & $185(79.7)$ \\
\hline
\end{tabular}


Tabel 2. Tingkat pengetahuan

\begin{tabular}{|c|c|c|c|}
\hline No. & Pertanyaan & Benar (\%) & $\begin{array}{r}\text { Salah } \\
(\%)\end{array}$ \\
\hline \multirow[t]{4}{*}{1.} & \multicolumn{3}{|l|}{ Pengertian swamedikasi dan suplemen } \\
\hline & $\begin{array}{l}\text { 1. Swamedikasi adalah mengobati penyakit atau gejala } \\
\text { dengan menggunakan obat tanpa resep dokter }\end{array}$ & 96,2 & 3,8 \\
\hline & $\begin{array}{l}\text { Suplemen kesehatan tidak bisa menggantikan zat gizi } \\
\text { dari makanan sehari-hari }\end{array}$ & 84,1 & 15,9 \\
\hline & $\begin{array}{c}\text { Rata-rata } \\
\text { Pemilihan suplemen dan vitamin }\end{array}$ & 90,2 & 9,9 \\
\hline \multirow{2}{*}{2.} & $\begin{array}{l}\text { 1. Obat tradisional bukan termasuk suplemen tetapi dapat } \\
\text { digunakan untuk meningkatkan imunitas }\end{array}$ & 92,7 & 7,3 \\
\hline & $\begin{array}{c}\text { Rata-rata } \\
\text { Cara mendapatkan suplemen }\end{array}$ & 92,7 & 7,3 \\
\hline \multirow{2}{*}{3.} & $\begin{array}{l}\text { Suplemen dapat dibeli secara bebas, aman dan terjamin } \\
\text { di apotek, toko obat berizin serta warung tetangga }\end{array}$ & 12,6 & 87,4 \\
\hline & \multicolumn{3}{|l|}{ Cara menggunakan suplemen } \\
\hline \multirow{5}{*}{4.} & $\begin{array}{l}\text { Suplemen cukup diminum satu kali sehari kecuali atas } \\
\text { rekomendasi dari dokter }\end{array}$ & 93,8 & 6,2 \\
\hline & $\begin{array}{l}\text { Vitamin C dapat meningkatkan imunitas tubuh karena } \\
\text { sebagai antioksidan dan penangkal radikal bebas }\end{array}$ & 99,7 & 0,3 \\
\hline & $\begin{array}{l}\text { Vitamin D dapat meningkatkan imunitas tubuh selama } \\
\text { pandemic COVID-19 }\end{array}$ & 88,7 & 11,3 \\
\hline & $\begin{array}{l}\text { Selama masa pandemic COVID-19 penggunaan vitamin } \\
\text { E tidak dapat meningkatkan fungsi kekebalan tubuh }\end{array}$ & 56,7 & 43,3 \\
\hline & $\begin{array}{l}\text { Kebutuhan vitamin } \mathrm{D} \text { untuk semua kondisi cukup } \\
\text { dipenuhi dengan berjemur dibawah sinar matahari }\end{array}$ & 41,1 & 58,9 \\
\hline \multirow[t]{3}{*}{5.} & \multicolumn{2}{|l|}{ Cara penyimpanan suplemen } & 24 \\
\hline & $\begin{array}{l}\text { Suplemen dapat disimpan dalam suhu ruangan serta } \\
\text { terhindar dari sinar matahari langsung }\end{array}$ & 98,9 & 1,1 \\
\hline & Rata-rata & 98,9 & 1,1 \\
\hline \multirow[t]{3}{*}{6.} & \multicolumn{3}{|l|}{ Cara membuang suplemen yang kadaluwarsa } \\
\hline & $\begin{array}{l}\text { Suplemen yang sudah kadaluwarsa dapat dibuang } \\
\text { bersama sampah rumah tangga }\end{array}$ & 43 & 57 \\
\hline & Rata-rata & 43 & 57 \\
\hline
\end{tabular}


Tabel 3. Tingkat Perilaku

\begin{tabular}{|c|c|c|c|c|}
\hline No. & Pertanyaan & Setuju (\%) & Ragu-ragu (\%) & Tidak setuju (\%) \\
\hline \multirow[t]{3}{*}{1.} & \multicolumn{4}{|l|}{ Tepat cara mendapatkan suplemen } \\
\hline & $\begin{array}{l}\text { Selain diperoleh diapotek suplemen juga bisa } \\
\text { dibeli dari toko obat berizin }\end{array}$ & 90,3 & 8,3 & 1,3 \\
\hline & Rata-rata & 90,3 & 8,3 & 1,3 \\
\hline \multirow[t]{9}{*}{2.} & \multicolumn{4}{|l|}{$\begin{array}{l}\text { Tepat cara menggunakan : tepat dosis, efek samping, } \\
\text { tepat indikasi, kontraindikasi }\end{array}$} \\
\hline & $\begin{array}{l}\text { Suplemen kesehatan dapat dikonsumsi satu } \\
\text { kali dalam sehari } 1 \text { kapsul }\end{array}$ & 91,4 & 7,5 & 1,1 \\
\hline & $\begin{array}{l}\text { Ketika mengonsumsi suplemen peningkat } \\
\text { imunitas tubuh, tetap harus mewaspadai } \\
\text { munculnya efek samping }\end{array}$ & 94,4 & 5,1 & 0,5 \\
\hline & $\begin{array}{l}\text { Suplemen kesehatan bisa diminum sampai } \\
\text { habis. Apabila muncul efek samping yang tidak } \\
\text { dapat ditoleransi }\end{array}$ & 53,8 & 22,3 & 23,9 \\
\hline & $\begin{array}{l}\text { Obat tradisional untuk meningkatkan imunitas } \\
\text { tubuh lebih aman karena tidak memberikan } \\
\text { efek samping }\end{array}$ & 15,9 & 35,2 & 48,9 \\
\hline & $\begin{array}{l}\text { Mengonsumsi suplemen kesehatan untuk } \\
\text { meningkatkan imunitas tubuh merupakan salah } \\
\text { satu cara pencegahan COVID-19 }\end{array}$ & 96,5 & 3,2 & 0,3 \\
\hline & $\begin{array}{l}\text { Selain mengonsumsi suplemen dan vitamin, } \\
\text { vitamin } D \text { dapat diperoleh dengan berjemur } \\
\text { dibawah sinar matahari }\end{array}$ & 93,3 & 5,6 & 1,1 \\
\hline & $\begin{array}{l}\text { Apabila memiliki riwayat penyakit sebelumnya, } \\
\text { sebaiknya mengonsumsi suplemen/vitamin } \\
\text { hanya atas rekomendasi dokter }\end{array}$ & 89 & 8,1 & 3 \\
\hline & $\begin{array}{c}\text { Rata-rata } \\
\text { Tepat penyimpanan suplemen }\end{array}$ & 76,3 & 12,4 & 11,3 \\
\hline \multirow{2}{*}{5.} & $\begin{array}{l}\text { Suplemen dapat disimpan dalam suhu kamar } \\
\text { dan terhindar dari sinar matahari langsung }\end{array}$ & 97,6 & 2,4 & 0 \\
\hline & Rata-rata & 97,6 & 2,4 & 0 \\
\hline \multirow[t]{3}{*}{6.} & Tepat cara membuang suplemen yang kadaluwarsa & & & \\
\hline & $\begin{array}{l}\text { Suplemen yang telah kadaluwarsa dapat } \\
\text { dibuang bebas di tempat sampah }\end{array}$ & 48,4 & 23,1 & 28,5 \\
\hline & Rata-rata & 48,4 & 23,1 & 28,5 \\
\hline
\end{tabular}




\section{Pembahasan}

Sosiodemografi dalam penelitian ini meliputi : usia dan jenis kelamin. Dari hasil penelitian diketahui prevalensi mahasiswa yang mengonsumsi swamedikasi suplemen kesehatan peningkat imunitas sebesar $61,7 \%$. Berdasarkan penelitian yang dilakukan oleh Hamulka, et al (2020) menunjukkan bahwa penggunaan suplemen nutrisi seperti vitamin C, vitamin D, dan zinc meningkat selama pandemi COVID-19 ${ }^{(7)}$. Hal ini sejalan dengan penelitian yang dilakukan oleh Onchonga, Omwoyo dan Nyamamba (2020) yang menyebutkan bahwa prevalensi dari swamedikasi meningkat dari $36,2 \%$ sebelum pandemi menjadi $60,4 \%$ selama pandemi (8). Hal ini terjadi karena infodemik yang diterima masyarakat terkait upaya pencegahan tertularnya COVID-19 dengan meningkatkan imunitas tubuh yang salah satunya dengan mengonsumsi suplemen Kesehatan.

Berdasarkan tabel 1 dapat diketahui bahwa usia 16-20 lebih banyak melakukan swamedikasi dengan jumlah responden 185 (49,7\%). Hasil penelitian sebelumnya yang dilakukan oleh Lieberman, et al (2015) dalam penelitiannya tentang penggunaan suplemen di kalangan mahasiswa menunjukkan bahwa hasil penelitian pada rentang usia 16-23 tahun lebih banyak persentasenya dalam menggunakan suplemen (8). Usia merupakan salah satu faktor yang mempengaruhi seseorang dalam mengambil keputusan untuk melakukan pengobatan sendiri.

Berdasarkan karakteristik jenis kelamin dapat diketahui bahwa yang paling banyak melakukan swamedikasi dengan suplemen yaitu perempuan yaitu 299 (80,4\%). Hasil yang diperoleh sejalan dengan penelitian yang dilakukan oleh Irawati, Rumi dan Parumpu (2021) yang menunjukkan bahwa jenis kelamin yang paling banyak dilakukan oleh perempuan dengan persentase $83,67 \%$ dikarenakan mahasiswa kesehatan kebanyakan adalah perempuan. Jurusan Farmasi lebih banyak diminati oleh perempuan disbanding laki-laki (9) .

Pada penelitian ini tingkat pengetahuan responden dibagi menjadi 3 kategori yaitu baik, cukup baik dan kurang sedangkan pada tingkat perilaku dikategorikan dalam perilaku positif dan perilaku negatif. Tingkat pengetahuan dan perilaku akan swamedikasi dengan suplemen kesehatan menggunakan indikator DAGUSIBU sesuai dengan BPOM (2015) dalam materi edukasi tentang peduli obat dan pangan aman seperti cara mendapatkan suplemen, cara menggunakan yang meliputi dosis, indikasi, kontraindikasi dan efek samping, cara penyimpanan serta cara membuang suplemen yang kadaluwarsa ${ }^{(10)}$. Hasil terperinci ada pada tabel 2.

Pada pertanyaan nomor $1 \mathrm{~B}$ mengenai pengertian swamedikasi yang mana menurut Depkes RI (2006) menjelaskan bahwa swamedikasi adalah suatu upaya mengobati diri sendiri untuk mengatasi keluhan atau gejala dari suatu penyakit dengan obat-obatan yang dapat dibeli secara bebas di apotek ataupun toko obat tanpa resep dokter. Responden yang menjawab dengan benar tentang pengertian swamedikasi sebesar $96,2 \%$ dan pada pertanyaan nomor 2B tentang pengertian suplemen kesehatan sebanyak $84,1 \%$ yang menjawab benar. Pengertian suplemen kesehatan berdasarkan BPOM (2019) merupakan produk yang dimaksudkan sebagai pelengkap kebutuhan zat 
gizi makanan yang dapat mengandung satu atau lebih bahan berupa vitamin, mineral asam amino atau bahan lain yang berasal dari tumbuhan maupun bukan tumbuhan dan memiliki nilai gizi serta efek fisiologis dalam jumlah terkonsentrasi (11).

Pada indikator tentang pemilihan suplemen dengan pertanyaan nomor 11B bahwa obat tradisional bukan termasuk suplemen tetapi dapat digunakan untuk meningkatkan imunitas sebanyak 92,7\% responden menjawab benar. Menurut BPOM (2019) dijelaskan bahwa suplemen merupakan produk yang dimaksudkan untuk melengkapi kebutuhan zat gizi makanan, satu atau lebih bahan berupa vitamin, mineral, asam amino, atau bahan lain (berasal dari tumbuhan atau bukan tumbuhan) yang mempunyai nilai gizi dan atau efek fisiologis dalam jumlah terkonsentrasi sedangkan obat tradisional ialah bahan atau ramuan bahan yang berupa tumbuhan, bahan hewan, bahan mineral, sediaan sarian (gelenik) atau campuran dari bahan tersebut yang secara turun temurun telah digunakan untuk pengobatan dan dapat diterapkan sesuai dengan norma yang berlaku dimasyarakat ${ }^{(11)}$.

Indikator pengetahuan dan perilaku tentang cara mendapatkan suplemen pada nomor 6B dimana suplemen dapat dibeli secara bebas, aman dan terjamin di apotek, toko obat berizin serta warung tetangga dengan jawaban benar 12,6\% dan pertanyaan 1C menjawab tepat $90,3 \%$ dengan pertanyaan selain diperoleh di apotek suplemen juga bisa dibeli dari toko obat berizin hal ini menunjukkan bahwa tingkat pengetahuan responden termasuk dalam kategori tidak baik namun tingkat perilaku responden termasuk kategori positif. Berdasarkan penelitian Siahaan, et al (2017) dengan judul Pengetahuan, Sikap, dan Perilaku Masyarakat dalam Memilih Obat yang Aman di Tiga Provinsi di Indonesia diketahui bahwa apotek merupakan tempat terbaik untuk membeli obat, baik itu obat keras/OKT, obat bebas, vitamin/suplemen $(>75 \%){ }^{(12)}$. Berdasarkan materi tentang DAGUSIBU tempat yang aman dan tepat secara resmi diperoleh di apotek, toko obat berizin, klinik dan rumah sakit.

Berdasarkan indikator cara menggunakan suplemen yang tepat sesuai materi DAGUSIBU dijelaskan bahwa setiap obat punya manfaat, namun juga mempunyai efek samping yang merugikan sehingga gunakan obat sesuai dengan aturan pakainya. Cara menggunakan obat yang tepat salah satunya meliputi dosis yang terdapat pada nomor 7B dan 2C pertanyaan mengenai dosis bahwa suplemen cukup diminum satu kali sehari kecuali atas rekomendasi dokter banyak responden yang menjawab benar dan tepat dalam menggunakannya hal ini dapat menunjukkan bahwa tingkat pengetahuan responden baik dengan kategori perilaku yang positif. Berdasarkan penelitian yang dilakukan oleh Shakoor, et al (2021) menunjukkan bahwa asupan vitamin C 1g/hari dapat meningkatkan sekresi IL-10 oleh sel mononuclear darah perifer ${ }^{(13) .}$

Pertanyaan pada indikasi penggunaan suplemen nomor $3 \mathrm{C}$ mengonsumsi suplemen kesehatan untuk meningkatkan imunitas tubuh merupakan salah satu cara pencegahan COVID-19 banyak responden yang menjawab dengan tepat $96,5 \%$ termasuk dalam kategori positif. Suplemen kesehatan seperti nomor 3B menunjukkan pengetahuan yang baik dimana responden menjawab benar 99,7\% mengenai vitamin C yang menyatakan bahwa vitamin $\mathrm{C}$ dapat digunakan sebagai peningkat imunitas karena 
memiliki peran sebagai antioksidan dan radikal bebas. Selain itu nomor 4B dengan jawaban benar $88,7 \%$ tentang kebutuhan vitamin D juga dapat digunakan sebagai peningkat imunitas termasuk kedalam kategori baik. Menurut Kemendagri (2020), vitamin $\mathrm{D}$ dapat diperoleh dengan cara berjemur dibawah sinar matahari dan terdapat pada pertanyaan nomor 8B responden menjawab benar $41,1 \%$ dan $4 \mathrm{C}$ menjawab dengan tepat 93,3. Berdasarkan Protokol penatalaksanaan COVID-19 berjemur yang dianjurkan yaitu sekitar 10-15 menit pada sebelum jam 9 pagi dan setelah jam 3 sore hanya saja jika terjadi defisiensi vitamin D makan tidak cukup dipenuhi dengan hanya berjemur.

Suplemen seperti vitamin E juga dipercaya dapat sebagai peningkat daya tahan tubuh terdapat nomor 5B. Kekurangan vitamin E dipercaya berkontribusi terhadap menurunnya sistem kekebalan tubuh, oleh sebab itu dengan memenuhi asupan vitamin E dipercaya dapat menjaga dan meningkatkan sistem kekebalan tubuh. Pada mekanisme imun, vitamin $\mathrm{E}$ terlibat dalam mempertahankan atau meningkatkan aktivitas sitotoksik sel NK dan menghambat produksi PEG2 oleh makrofag sehingga secara tidak langsung dapat melindungi fungsi sel T. Suplementasi nutrisi dalam COVID-19 berperan penting untuk mengurangi gejala dan infeksi pernapasan yang disebabkan oleh COVID-19. Peran mineral seperti zinc juga dapat meningkatkan respons imun dan menekan replikasi virus ${ }^{(13)}$.

Mengonsumsi suplemen peningkat imunitas tetap harus mewaspadai munculnya efek samping. Terlalu banyak mengonsumsi vitamin $\mathrm{C}$ dapat menyebabkan diare, mual, kram perut dan gangguan pada lambung lainnya karena efek osmotik dari vitamin $C$ yang tidak terserap dalam saluran gastrointestinal. Pertanyaan pada nomor 10C dimana obat tradisional untuk meningkatkan imunitas tubuh lebih aman karena tidak memberikan efek samping. Banyak responden yang menjawab dengan tidak setuju dengan persentase 48,9\%. Efek samping obat merupakan respon obat yang merugikan dan tidak diharapkan terjadi pada manusia pada penggunaan dosis pemakaian. Tanyakan pada tenaga kesehatan efek samping apa yang mungkin terjadi dan apa yang harus dilakukan jika muncul efek samping tersebut. Obat tradisional seperti temulawak juga memiliki efek samping, hal ini sesuai dengan Keputusan Menteri Kesehatan Republik Indonesia Nomor HK.01.07/MENKES/187/2017 tentang Formularium Ramuan Obat Tradisional Indonesia yang menunjukkan bahwa temulawak apabila pemakaian jangka panjang dapat merangsang lambung atau dapat menyebabkan iritasi lambung ${ }^{(14)}$.

Pada indikator cara penyimpanan suplemen nomor 9B dan 8C menunjukkan pengetahuan yang baik dengan perilaku yang positif. Penyimpanan obat dirumah tangga secara umum yaitu jauhkan dari jangkauan anak-anak, simpan obat dalam kemasan asli dan dalam wadah tertutup rapat, simpan obat ditempat yang sejuk dan terhindar dari sinar matahari langsung atau ikuti aturan yang tertera pada kemasan, jangan tinggalkan obat di dalam mobil dalam jangka waktu lama karena suhu yang tidak stabil dalam mobil dapat merusak sediaan obat serta jangan simpan obat yang kadaluwarsa. 
Indikator berikutnya mengenai cara membuang suplemen yang kadaluwarsa pada nomor 10B dan 9C banyak responden yang tidak mengetahui secara benar dan tepat mengenai cara membuang suplemen yang kadaluwarsa, sehingga hal ini dapat menunjukkan bahwa pengetahuan responden termasuk dalam kategori kurang baik dengan tingkat perilaku negatif. Obat yang kadaluwarsa jangan disimpan atau jangan dibuang sembarangan supaya tidak disalahgunakan. Obat yang akan dibuang terlebih dahulu dibuka dari kemasannya, direndam dalam air kemudian dipendam dalam tanah.

Soal nomor $5 \mathrm{C}$ mengenai kontraindikasi dengan pertanyaan apabila memiliki riwayat penyakit sebelumnya sebaiknya mengonsumsi suplemen/vitamin hanya atas rekomendasi dokter, dalam item pertanyaan tersebut banyak responden yang menjawab dengan tepat sehingga dapat dikategorikan perilaku responden termasuk dalam perilaku positif. Pada orang dengan kondisi hemochromatosis dimana tubuh menyimpan banyak zat besi, penggunaan vitamin $C$ dengan dosis tinggi dapat memperburuk kelebihan zat besi dan merusak jaringan tubuh. Konsumsi vitamin $C$ yang tinggi juga berpotensi untuk meningkatkan kadar oksigen pada saluran kemih dan ekskresi asam urat yang dapat turut membentuk pembentukan batu ginjal. Beri tahu dokter, apoteker, dan penyedia layanan kesehatan lainnya tentang suplemen yang akan diminum

Dari hasil analisis dapat diketahui bahwa mayoritas tingkat pengetahuan responden dikategorikan cukup baik 58,9\%. Pada tingkat perilaku responden dapat diketahui bahwa tingkat perilaku responden termasuk dalam kategori positif $(56,2 \%)$. Hasil penelitian tentang pengaruh usia terhadap pengetahuan ini sesuai dengan penelitian yang dilakukan oleh Onchonga, Omwoyo dan Nyamamba (2020) dimana usia memiliki pengaruh terhadap swamedikasi ditengah pandemi COVID-19 diketahui hasil $p$ value $0.014 \leq 0.05^{(8)}$. Sedangkan pada tingkatan usia dengan perilaku diketahui nilai $p$ value $0.617>0.05$ yang berarti tidak bermakna signifikan. Menurut Utama (2020) sesuai dengan tingkat kematangan usia seseorang akan lebih cenderung lebih cepat menerima informasi serta mudah dalam menerima perubahan perilaku ${ }^{(15)}$. Perilaku adalah suatu respon atau reaksi seseorang terhadap rangsangan dari luar, tetapi usia tidak bisa dijadikan standar terhadap perilaku dimana semakin bertambahnya usia belum tentu menyebabkan perilaku seseorang semakin baik.

Hasil analisis menggunakan uji chi-Square, pengaruh jenis kelamin dengan pengetahuan dan perilaku menunjukkan nilai $p$ value $\leq 0,05$ yang artinya berpengaruh secara bermakna. Menurut Onchonga, Omwoyo dan Nyamamba (2020) juga dijelaskan bahwa perempuan lebih banyak melakukan pengobatan sendiri selama pandemi COVID-19. Perempuan mempunyai ambang nyeri yang rendah dan memiliki perilaku pencarian kesehatan yang lebih baik dari pada laki-laki, kunjungan rumah sakit yang rutin sehingga perempuan lebih akrab dengan obat yang mengakibatkan mereka lebih banyak melakukan pengobatan diri sendiri (16). 


\section{Kesimpulan}

1. Ada pengaruh usia terhadap pengetahuan penggunaan suplemen kesehatan ( $p$ value $0.000 \leq 0.05$ ) tetapi tidak ada pengaruh usia terhadap perilaku penggunaan supleme di amsa pandemic ( $p$ value $0.617>0.05$ ) pada mahasiswa S1 Farmasi IIK Bhakti Wiyata Kediri

2. Ada pengaruh jenis kelamin terhadap pengetahuan serta perilaku penggunaan suplemen di masa pandemi ( $p$ value $\leq 0.05$ ) pada mhasiswa S1 Farmasi IIK Bhakti Wiyata Kediri

\section{Ucapan Terimakasih}

Terima kasih kepada Dekan Fakultas Farmasi IIK Bhakti Wiyata Kediri. Artikel ini telah dipaparkan pada Pertemuan IImiah Tahunan Virtual Ikatan Apoteker Indonesia tahun 2021.

\section{Daftar Pustaka}

1. Departemen Kesehatan RI. Undang-Undang Republik Indonesia Nomor 36 tahun 2009 Tentang Kesehatan. Jakarta: Kementerian Kesehatan RI.

2. Kemendagri. Pedoman Pencegahan dan Pengendalian Coronavirus Disease (Covid-19). Jakarta: Direktorat Pencegahan dan Pengendalian Penyakit. 2020.

3. Departemen Kesehatan RI.. Pedoman Penggunaan Obat Bebas dan Bebas Terbatas. Jakarta: Departemen Kesehatan Republik Indonesia. 2006.

4. Bauer, S.R., Kpoor,A., Rath, M., Thomas, S.A.. What is The Role of Supplentation with Ascorbic Acid, Zinc, Vitamin D, or $\mathrm{N}$-acetylcysteine for Prevention or Treatment of COVID-?. Cleveland Clinic Journal of Medicine, 2020 : 3-5

5. Tursina, et.al.. Kopidpedia Bunga Rampai Artikel Penyakit Virus Corona (Covid19). Bandung: Pusat Penerbitan Universitas (P2U) Unisba. 2020

6. Aswad, P.A., Yuktiana, K., Yuke, A., Titik, R., Eka, N.. Pengetahuan dan Perilaku Swamedikasi oleh Ibu-lbu di Kelurahan Tamansari Kota Bandung. Jurnal Integrasi Kesehatan dan Sains 2019; 01(02) : 107-113

7. Hamulka, J., Jeruszka-Bielak, M., Górnicka, M., Drywień, M. E., \& ZielinskaPukos, M. A. Dietary supplements during covid-19 outbreak. Results of google trends analysis supported by plifecovid-19 online studies. Nutrients, 2021; 13(1), $1-17$. 
8. Onchonga, D., Omwoyo, J., Nyamamba, D. Assessing The Prevalence of Selfmedication among Healthcare Workers Before and During The 2019 SARS-CoV-2 (COVID-19) Pandemic in Kenya. Saudi Pharmaceutical Journal, 2020; 28 (10), 1149-1154

9. Lieberman, H. R., Marriott, B. P., Williams, C., Judelson, D. A., Glickman, E. L., Geiselman, P. J., Dotson, L., \& Mahoney, C. R.. Patterns of dietary supplement use among college students. Clinical Nutrition, 2015; 34(5), 976-985.

10. Irawati R., Rumi A., and Parumpu FA. Swamedikasi Obat Analgesik Pada Mahasiswa Universitas Tadulako Di Kota Palu. Jurnal Health Sains 2021; Vol 2(03) : Maret : 350-361

11. Badan POM. Peduli Obat dan Pangan Aman. Gerakan Nasional Peduli Obat Dan Pangan Aman, 7-8, 20. 2015.

12. Siahaan, S. A. S., Usia, T., Pujiati, S., Tarigan, I. U., Murhandini, S., Isfandari, S., \& Tiurdinawati, T. Pengetahuan, Sikap, dan Perilaku Masyarakat dalam Memilih Obat yang Aman di Tiga Provinsi di Indonesia. Jurnal Kefarmasian Indonesia, 2017; 7(2), 136-145. https://doi.org/10.22435/jki.v7i2.5859.136-145

13. Shakoor, H., Feehan, J., Al, A. S., Ali, H. I., Platat, C., Cheikh, L., Apostolopoulos, V., \& Stojanovska, L. Since January 2020 Elsevier has created a COVID-19 resource centre with free information in English and Mandarin on the novel coronavirus COVID-19. The COVID-19 resource centre is hosted on Elsevier Connect, the company's public news and information . January. 2020.

14. Izazi, F., \& Kusuma P, A. Hasil Responden Pengetahuan Masyarakat Terhadap Cara Pengolahan Temulawak (Curcuma Xanthorrhiza) dan Kencur (Kaemferia galanga) Sebagai Peningkatan Imunitas Selama COVID-19 dengan Menggunakan Kedekatan Konsep Program Leximancer. Journal of Pharmacy and Science, 2020; 5(2), 93-97.

15. Utama, L. J.. Gaya Hidup Mayarakat Nusa Tenggara Timur Dalam Menghadapi Pandemi Corona Virus Disease 19 (Covid-19). Jurnal Kesehatan Masyarakat, 2020; 7(1), 34-40.

16. Giriraju, A.. Perception about self-medication practices for oral health problems among the general population of Davangere city, Karnataka, India. J Indian Assoc Public Health Dent. 2014; Vol 12(3):219. 